\title{
Excellent Mentor Teachers' Skills in Mentoring for Pre-Service Teachers
}

\author{
Shih-Hsiung Liu ${ }^{1, *}$ \\ ${ }^{1}$ Center for Teacher Education, National Changhua University of Education, No.1 Jin-De \\ Road, Changhua city 500, Taiwan \\ *Correspondence: Tel: 886-4-723-2105 E-mail: shsiung@cc.ncue.edu.tw
}

Received: June 22, $2014 \quad$ Accepted: July 4, $2014 \quad$ Published: July 28, 2014

doi:10.5296/ije.v6i3.5855 URL: http://dx.doi.org/10.5296/ije.v6i3.5855

\begin{abstract}
This study aims to identify the performances of 76 Taiwanese awarded mentor teachers in mentoring pre-service teachers by analyzing their written reports related to mentoring processes. An inductive content analysis method was used to construct headings and codes in relation to mentoring skills. The analytical result reveals that 448 headings were formed and were further categorized into six groups, reported as six mentoring skills. The mentoring skills rank-order from high to low frequencies are as follows: employing the built model as a framework for teaching guidance, guiding interpersonal interactions, fostering career competitive ability, encouraging reflections on internship experiences, creating mentoring plan through discussions with pre-service teachers, and giving emotional supports. Like the previous studies, the study finding reveals that the person-oriented supports like giving emotional supports, only accounting for $1.3 \%$, seem to be unusually used by Taiwanese mentor teachers.
\end{abstract}

Keywords: mentor teacher, pre-service teacher, mentoring skill, field-based practicum 


\section{Introduction}

Participating in field-based practicum experiences is a vital part of teacher education program. The field-based practicum should establish conditions to make pre-service teachers thoughtful and to equip them with the ability to enhance students' education (Zeichner, 1996). Specifically, the aim of field-based practicum should be educative: it should help pre-service teachers understand the role of teacher, foster the pre-service teachers' capacity to learn from field experiences, and accomplish the central task of teaching-helping pupils to learn (Graham, 2006, p. 1119). To achieve effectiveness in field-based practicum experiences, a mentor teacher's role is established to support pre-service teachers during field-based practicum experiences.

Minister of Education of Taiwan strongly emphasizes on quality of mentor teachers and has awarded 76 mentor teachers for their contribution to field-based practicum experiences since 2006. The mentoring skills of the excellent mentor teachers are concerned. Previous studies have indicated the approaches on specific skills in mentoring of general mentors (Crasborn, \& Hennissen, 2010; Hennissen, Crasborn, Brouwer, Korthagen, \& Bergen, 2011; Rajuan, Beijaard \& Verloop, 2007; Rippon, \& Martin, 2006); however, few studies identified the quality of mentoring work of excellent mentor teachers for pre-service teachers. This study aims to identify the performances of 76 Taiwanese awarded mentor teachers in mentoring for pre-service teachers.

\section{Literature Review}

\subsection{The role of mentor teacher}

Mentor teacher means that a more experienced teacher than a mentee possesses knowledge and skills desired by the mentee (Ambrosetti \& Dekkers, 2010). During mentoring, mentor teachers are often regarded as a subject for learning educational practice by pre-service teachers. This above approach reflects the existence of a hierarchical relationship between a mentor and a mentee.

The role of mentors is often replaced by terms such as guide, advisor, counselor, instructor, sharer, supporter and encourager (Bray \& Nettleton, 2006; Sundli, 2007; Hall, Draper, Smith \& Bullough, 2008). According to studies (Hall et al. 2008; Hawkey, 2006; Le Maistre, Boudreau \& Pare, 2006; Schwille, 2008), mentors can provide not only pedagogical guidance, emotional support and professional socialization, but also empathy and serve as role models. Considering that teachers' knowledge and skills are event-structured, context-based, and practice-oriented in nature (Kessels \& Korthagen, 1996), mentor teachers have multiple roles. Despite these multiple roles in the mentoring approach, many mentor teachers recognize their position more as an advisor and imperator, who gives instructions and suggestions on teaching practice, than as an encourager of reflection on concrete thoughts and actions in the classroom (Feiman-Nemser, 2000; van Ginkel, Vermunt, Verloop, \& Beijaard, 2005).

Additionally, mentoring strategies are flexible because pre-service teacher's learning is 
influenced by personal characteristics as well as contextual factors. Katz (2003) determined that pre-service teachers' professional development takes place at differing paces, resulting in that their needs and concerns change over time. Erau (2007) indicated that how a person acquires a specific set of knowledge and skills is strongly intertwined with the situation in the workplace in which this person is learning. Thus, if mentor teachers become good at adapting to mentoring situations in which they employ differentiated mentoring project for pre-service teachers with different characteristics, pre-service teachers' learning may improve. No one supervisory approach is effective for all pre-service teachers (Glickman \& Bey, 1990, p. 560). Mentor teachers need to assure that the mentoring roles they take and the strategies they use to support mentees' learning are related to their mentees' concerns and suitable for their current stages of professional development (Hennissen, et al., 2011).

Furthermore, mentors and pre-service teachers can collaboratively develop teaching knowledge while cooperating in a school context (Nilsson \& van Driel, 2010). A perspective considers mentoring in teacher education as complex social interactions that mentor teachers and pre-service teachers construct and negotiate for various professional purposes and in response to contextual factors (Fairbanks, Freedman \& Kahn, 2000). For example, mentor teachers can reflect on their own instructional practice through the interaction with pre-service teachers after mentor teachers request pre-service teachers to observe their own instructional skills or strategies being used in classroom. Studies have demonstrated the effectiveness in collaboration between pre-service and in-service teachers (Chen, 2012) and showed that the advantages of collaboration include mutual learning and the provision of professional support (Goodnough, Osmond, Dibbon, Glassman \& Stevens, 2009; Spilková, 2001; Stanulis \& Russell, 2000). The new relationship between mentors and interns, unlike the traditional apprenticeship, provides the opportunities of collaboration on teaching practice.

\subsection{The mentoring skills}

Mentoring dialogue in field-based practicum is an important strategy for helping pre-service teachers develop professional knowledge and transform existing teaching practices (Crasborn, Hennissen, Brouwer, Korthagen, \& Bergen, 2010; Hiebert, Gallimore, \& Stigler, 2002). The dialogue makes pre-service teachers go beyond their individual frames of reference and makes them consider new conceptions and knowledge about teaching (Knežić, Wubbels, Elbers, \& Hajer, 2010).

In addition to the development of teaching competencies (Lindgren, 2005), mentors positively play a key role in pre-service teachers' socialization process (Bullough \& Draper, 2004) and provide them with emotional and psychological support (Marable \& Raimondi, 2007). Rajuan, et al. (2007) indicated the three main areas of perceived assistance: 1). person-oriented, which includes the creation of trust and safety; 2). practice-oriented, including information sharing about pupils and ways to make lessons more interesting; and 3). technique-oriented, including specific skills about lesson planning and classroom management. Hennissen, et al. (2011) identified that six types of mentoring skills appeared to be perceived by pre-service teachers as offering emotional support and five others as offering 
task assistance. Effective mentors provide their mentees with emotional and psychological support, and make them feel welcome, accepted and included (Rippon, \& Martin, 2006). The emotional support has been shown to be helpful in boosting the confidence of beginner teachers, enabling them to put difficult experiences into perspective, and increasing their morale and job satisfaction (Bullough, 2005; Marable \& Raimondi, 2007). However, mentor teachers do not always succeed in finding an adequate combination of offering emotional support and task assistance that is considered as an adequate mentoring by pre-service teachers (Crasborn, \& Hennissen, 2010).

In order to help mentor teachers obtain the ability to adaptively guide pre-service teachers with different characteristics, the university with teacher education department should organize meetings and training sessions on how and when to use different supervision approaches. However, studies have evaluated the effects of training programs focusing on supervisory skills for mentor teachers and suggested that mentor teachers hardly change their supervisory styles in response to the changing needs of students (Copeland, 1982; Williams, Butt, Gray, Leach, Marr \& Soares; Veenman \& Denessen, 2001). The above studies indicate that mentor teachers, either consciously or subconsciously, stick to a certain supervisory style. Mentoring performances seems to only emphasize practice-oriented and technique-oriented skills, and neglect person-oriented approach.

\section{Methodology}

This study focuses on the mentoring processes of the awarded mentor teachers by analyzing their written mentoring reports. According to previous studies, content analysis method allows a researcher to test theoretical issues to enhance understanding of the data (Elo \& Kyngas, 2007) and to identify critical processes (Lederman, 1991). Additionally, content analysis is used in an inductive or deductive way depending on the purpose of study. The inductive approach is used by moving from the specific to the general, so that particular instances are observed and then combined into a larger whole or general statement (Chinn \& Kramer 1999). Conversely, the deductive approach is based on an earlier theory or model and therefore it moves from the general to the specific (Burns \& Grove 2005). These approaches have similar preparation phases. Since the awarded mentors provided written reports that described their mentoring processes, this study mainly employed inductive content analysis approach to analyze the data and to identify critical mentoring skills that were used in field-based practicum experiences.

\subsection{Data resources}

Over the last eight years, National Changhua University of Education in Taiwan has conducted Educational Practice Award competition annually and selected excellent mentor teachers for praising them for their endeavor in field-based practicum experiences. Any mentor teacher who has at least three years of mentoring experiences can apply for the award. All mentor teachers who enrolled in the Award-competition need to write their mentoring processes into a required file volume and submitted file data to a committee board. The 
required data about mentoring records did not limit to any approach in relation to mentoring strategies. However, the participants were expected to write down the contents of their interaction with pre-service teachers. A total of 76 mentor teachers, as Table 1 shown, for their contribution to practicum experiences were awarded. The awarded teachers' file data in relation to mentoring behaviors are the main data of this study.

Table 1. The number of people of the awarded mentors since 2006

\begin{tabular}{lccccccccc}
\hline & 2006 & 2007 & 2008 & 2009 & 2010 & 2011 & 2012 & 2013 & total \\
\hline secondary school teacher & 6 & 6 & 3 & 3 & 3 & 2 & 2 & 1 & 26 \\
primary school teacher & 12 & 8 & 7 & 2 & 2 & 2 & 1 & 2 & 36 \\
pre-school teacher & 1 & 1 & 3 & 1 & 0 & 1 & 2 & 1 & 10 \\
special education teacher & 1 & 0 & 0 & 0 & 1 & 1 & 0 & 1 & 4 \\
\hline
\end{tabular}

\subsection{Process of data analysis}

This study employed the three processes of inductive content analysis, preparation, organizing and reporting, according to the perspectives from Elo and Kyngas (2007). Additionally, in order to obtain confirmability, three trained researchers independently reviewed the data, developed analytic headings and codes, and afterward, met to reach a consensus on the written reports of the awarded mentors. When grouping a pattern of headings, we again reviewed the analytical results to confirm any trends among the various data. We triangulated the reliability of the data analysis to achieve credibility, and further identified the mentoring skills of the awarded mentor teachers.

Moreover, data analysis involved using a process of constant comparisons for recurring words and emerging patterns (Lincoln \& Guba, 1985). Specifically, in the preparation phase of content analysis, we collected the unit of analysis from all awarded teachers' written texts and made sense of the relationships between the above units and the mentoring behaviors. Secondly, we opened codes, created categories and abstraction in the organizing phase. The written texts were read through again and as many headings as necessary were written down in the margins to describe all aspects of the content. When forming many headings, this study built the lists of categories that contained various headings. The categories provided a means of describing the phenomenon, increase the understanding and generate knowledge. Afterward, each category was named using content-characteristic words as an abstraction process. The abstraction process was as far as reasonable and possible.

\section{Results}

By reading all written texts, a total of 448 headings were formed and were further categorized into six groups in Figure 1, reported as six mentoring skills. Additionally, the analytical results also reveal that the mentors perceive the benefits of mentorship on their professional development. 


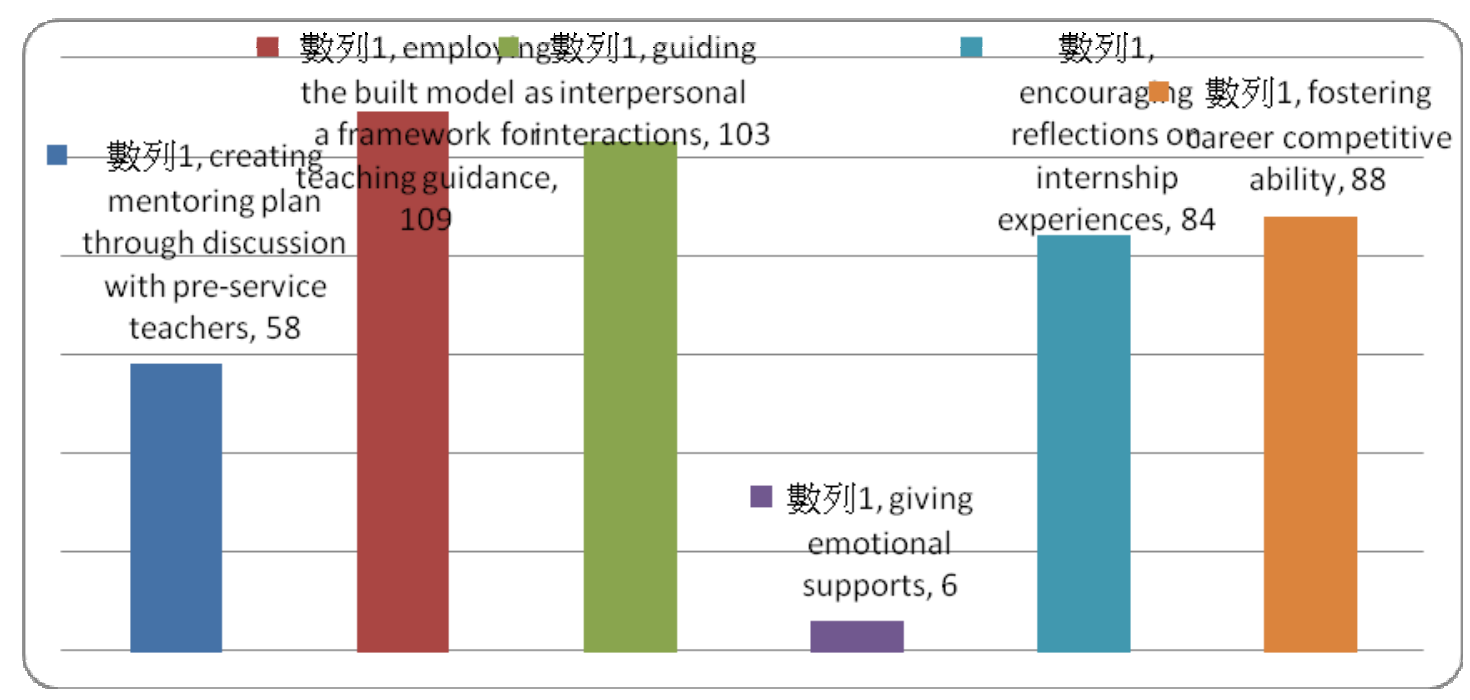

Figure 1. Statistical distribution of frequencies of six mentoring skills

\subsection{Creating mentoring plan through discussions with pre-service teachers}

As mentioned, no one supervisory approach is effective for all pre-service teachers (Glickman \& Bey, 1990, p. 560). The analytical result reveals that 58 headings were involved in formation of mentoring plan. Mentor teachers often initiated the dialogue with pre-service teachers for building positive mentor-intern relationship. During dialogue, mentors encouraged pre-service teachers to express their perspectives and expectations about field experiences and anxiety for career competitive ability. Through constant dialogue, they built a set of phases of field experiences in relation to mentoring plan.

I shared my perspectives on mentorships and he expressed his expectations as well as anxiety on future career. I told him that formation of a mentoring plan as well as implementation is our common tasks.... We divided the plan into five phases, including building confidence, teaching rehearsal, facilitating reflection, fostering competitive ability, and constructing learning situation for students.

The above finding reveals that the excellent mentor teachers have considered pre-service teachers' personal characteristics as well as their expectations when they collaboratively created mentoring plan. The effective dialogue helps the awarded mentors build a mentoring plan that is adaptive to pre-service teachers.

\subsection{Employing the built model as a framework for teaching guidance}

Except for administrative practice, teaching practice is the most vital element of practicum experiences for pre-service teaching. Generally, pre-service teachers actively discuss instructional plan with their mentors before teaching rehearsal. After teaching, mentors would indicate pre-service teachers' advantages and shortcomings in teaching activities. Notably, in this study, most of the awarded mentor teachers recognized that they have built one or two models of mentoring in teaching practice based on their previous experiences and guided their pre-service teachers to practice teaching activities and self-reflection through those models. 
I often encouraged my pre-service teacher to carefully read the unit content and further to think what kind of instructional strategies could be used. Additionally, I discussed instructional plan with him and inquired him how to deal with possible problems from students in each instructional step after he finished the initial instructional plan. After teaching, I would require pre-service teachers to express his perceptions on teaching activities and to reflect on each practice that happened in teaching situation. In final, I encouraged him to write down his changes in instructional ideas. The above procedures have almost become my model of guiding pre-service teachers, especially on teaching practice.

In Taiwan, at least three years of teaching experiences can qualify a teacher for a mentor teacher. Moreover, a mentor teacher with at least three years of mentoring experiences can apply for the Educational Practice Award. That is, the awarded mentor teachers have many experiences regardless of in teaching or in mentoring. They integrated teaching experiences into mentoring experiences and built a mentoring model. The model benefits their mentoring for pre-service teachers.

\subsection{Guiding interpersonal interactions}

Interpersonal relationships play an important role in practicum experiences for pre-service teachers. Pre-service teachers conceive of teaching primarily as a task involving affective, interpersonal relationships rather than a profession requiring a skilled and knowledgeable practitioner (Fajet, Bello, Leftwich, Mesler, \& Shaver, 2005). Most awarded mentors in this study recognized that the interpersonal relationships of pre-service teachers influence their interaction with children as well as parents and may alter their learning resources from mentors and other faculties. Thus, in addition to teaching skills, mentor teachers have noticed the quality of pre-service teachers' interpersonal interaction with others.

To assist him managing classroom with reasonable authority, I declare that the pre-service teacher is like a qualified teacher when I introduce my pre-service teacher to my students....I often share the experiences about how to contact parents, especially for irrational parents.

I actively led my pre-service teacher to call on other teachers as well as administrators and guided him to courteously contact other faculty. I think that the action could help him build positive interpersonal relationships with others. By positive interpersonal relationships, they could obtain many learning opportunities from other teachers.

As stated by Zeichner (1996), the field-based practicum should establish conditions to equip pre-service teachers with the ability to enhance students' education. Notably, positive interpersonal relationship is a key to initiate various learning activities during field-based practicum. The awarded mentors have recognized the importance of positive interpersonal relationships for pre-service teachers in mentoring and further help pre-service teachers initiate interpersonal relationships with all persons in the school.

\subsection{Giving Emotional Supports}

According to Moir (2003, p.60), mentors should decrease the isolation of the new teacher. The analytical result reveals that only six headings involved emotional supports for 
pre-service teachers. In contrast to other items in relation to mentoring skills, the most of mentor teachers did not emphasize giving emotional supports to pre-service teachers. A mentor expressed how she gave emotional supports to per-service teachers who per-service teachers confronted problems and conceived anxiety.

A pre-service teacher entering into teaching practice in pre-school situation is uneasy, especially when they need to contact other teachers, children as well as parents. They are anxious in implementing instructional activities, classroom management, and parent-teacher interaction. I comforted her and suggested her to calm down and further to think about the nature of the problems when they confronted specific problems. I also shared my previous experiences with frustration to her and supported her to go beyond the barriers.

A mentor's emotional support is essential when their pre-service teachers confront obstacles and perceive frustration. However, only a couple of awarded mentors mentioned their encouragement to pre-service teachers in this study. As mentioned by Birkeland and Feiman-Nemser (2012), the mentor teachers seem to see themselves as educative companions rather than the person offering emotional support. The awarded mentors might not know how to activate pre-service teachers.

\subsection{Encouraging Reflections on Internship Experiences}

Mentor teachers have to develop knowledge and supervisory skills in being effective in stimulating their pre-service teachers towards reflection. If pre-service teachers lack skills in professional reflection and self evaluation, the ultimate benefit they received from the practicum experience will be reduced. In this study, the mentors encouraged pre-service teachers to share experiences, which often led to dialogue and reflection.

I recognized that my pre-service teacher should talk more than me after his teaching rehearsal. When he expressed opinions in teaching activities, I would follow his words and encouraged him to think about other potential strategies for a perfect teaching context. This process could facilitate him to find the gaps between his teaching process and ideal teaching situation.

Making a self-reflection is a good way to help pre-service teachers understand what they need to work on, what they are doing well, and why it is working well. The awarded mentors created opportunities during dialogue and facilitated pre-service teachers to reflect on instructional processes. The dialogue about pre-service teachers' performance seems to be a good initiative for self-reflection in mentoring.

\subsection{Fostering Career Competitive Ability}

Fostering various abilities of pre-service teachers to become an excellent teacher as well as to obtain an employment certificate from a school seems to be a vision for most of mentor teachers in Taiwan. The mentor teachers of this study not only often guide pre-service teachers about the exam skills, but also encourage them to participant in various learning activities through mentors' guidance.

In addition to general teaching professional development, I hope my pre-service teachers to foster other abilities to confront future teachers' recruitment examination and further confront 
various problems in educational situation. I encouraged him to participant in a variety of training activities, including sports, digital material, language arts and various competitions for obtaining a certificate of award.

Since Taiwanese pre-service teachers need to register for teachers' recruitment examination after finishing field-based practicum, the awarded mentor teachers extended general mentoring works and added the guidance on recruitment exam of teacher for pre-service teachers.

\subsection{Perceiving Mutual Development Except for Mentoring Skills}

As mentioned by previous studies (Goodnough, Osmond, Dibbon, Glassman \& Stevens, 2009; Spilková, 2001; Stanulis \& Russell, 2000), the advantages of collaboration between pre-service and mentor teachers have emerged in this study, revealing 32 headings. A phrase of description from an awarded mentor is cited as follows.

I think that a pre-service teacher should be a cooperator with mentor teacher rather than a learner. In mentoring process, thus, both of the mentors and interns have common responsibility to achieve the purpose of field experiences.... When I dialogued with him, I found that my dialogue skills improved....Both of us acquired strategic knowledge through mutual dialogue.

Even though not many mentors showed up the perspectives on mutual professional development, a few of mentors recognized that the mentorship benefits their professional development.

In sum, like previous studies, indicating person-oriented, practice-oriented and technique-oriented supervisory skills, the analytical results of this study involve mentoring skills on interpersonal, teaching, reflection, and even emotional support. However, in terms of frequencies, the awarded mentors implemented practice-oriented and technique-oriented skills in mentoring more than person-oriented supports for pre-service teachers.

\section{Conclusion and Discussion}

This study aims to identify the excellent performance of awarded mentor teachers in mentoring for pre-service teachers in field-based practicum experiences and categorizes their mentoring performances as six mentoring skills. The six mentoring skills rank-order from high to low frequencies are as follows: employing the built model as a framework for teaching guidance, guiding interpersonal interactions, fostering career competitive ability, encouraging reflections on internship experiences, creating mentoring plan through discussion with pre-service teachers, and giving emotional supports. Additionally, this study also reveals that mentors perceived their professional development via mentoring.

In terms of relationships between mentor teachers and pre-service teachers, most mentors in the study recognized that the relationship of both tends to be partners rather than master-apprentice. The mentors did open their mind to understand the needs of pre-service 
teachers through constant dialogue. As the perspective from Hennissen et al. (2011), the mentors of this study noticed their mentees' concerns and adaptations for their current stages of professional development. Moreover, even though no much mentoring performances (only 32 headings) refer to the collaboration of mentors and pre-service teachers, some awarded mentors have perceived the benefits on professional development when guiding pre-service teachers, similar to the literature (Goodnough, et al., 2009; Spilková, 2001; Stanulis \& Russell, 2000), indicating effectiveness and advantages of mutual learning during mentoring.

As for mentor teachers' supervisory skills, previous literature refers to three main facets of person-oriented, practice-oriented and technique-oriented skills (Rajuan, et al., 2007) and indicated that mentors implement practice-oriented and technique-oriented approaches, including teaching skills, interpersonal interactions and career competitive ability, rather than person-oriented supports for pre-service teachers. The findings of this study are similar to the previous perspectives. The person-oriented supports like giving emotional supports, only accounting for $1.3 \%$, seem to be unusually used.

Ideally, the university with teacher education department should provide mentor teachers with training program for their student teachers. In Taiwan, a total of 54 universities with teacher education department locate around the country. However, due to a lack of budget for teacher education departments and spare time for mentor teachers, the majority of teacher education departments only provide mentor teachers with mentoring handbooks instead of formal training lessons. The handbooks merely describe specific regulations as well as recordable table, so that most mentors guide pre-service teachers by individual ideology and previous experiences on mentorship. Notably, the awarded mentors of the study have begun to notice mentoring skills like concerning pre-service teachers' needs on field experiences and perceiving of advantages on mentoring for their own professional development. The above performances are superior to that of general mentors and could explain why the mentor teachers were awarded. However, the awarded mentors have less concern on pre-service teachers' emotional performance.

According to literature review (Crasborn, Hennissen, Brouwer, Korthagen, \& Bergen, 2010; Hiebert, Gallimore, \& Stigler, 2002), dialogue between mentors and pre-service teachers can help pre-service teachers develop professional knowledge and transform existing teaching practices. In addition to the benefits of professional knowledge, mentor teachers can recognize pre-service teachers' anxiety on field experiences and the needs of career competitive ability, and further adapt the mentoring strategies. Thus, for mentors, person-oriented mentoring skills like perceiving pre-service teachers' emotion and anxiety by dialogue and providing further guidance are still recommended, as discussed by previous investigations. Teacher education institutes in Taiwan should provide mentor teachers with training programs and should also remind their cooperating teachers to pay attention to pre-service teachers' emotional performance. 


\section{Acknowledgement}

The research is financed by National Science Council of the Republic of China, Taiwan. No. NSC-102-2410-H-018-027-

\section{References}

Ambrosetti, A., \& Dekkers, J. (2010). The Interconnectedness of the roles of mentors and mentees in pre-service teacher education mentoring relationships. Australian Journal of Teacher Education, 35(6), 42-55. http://dx.doi.org/10.14221/ajte.2010v35n6.3

Birkeland, S., \& Feiman-Nemser, S. (2012). Helping school leaders help new teachers: A tool for transforming school-based induction. The New Educator, 8(2), 109-138. http://dx.doi.org/10.1080/1547688X.2012.670567

Bray, L., \& Nettleton, P. (2006). Assessor or mentor? Role confusion in professional education. Nurse Education Today, 27, 848-855. http://dx.doi.org/10.1016/j.nedt.2006.11.006

Bullough, R. V. (2005). Being and becoming a mentor: school-based teacher educators and teacher educator identity. Teaching and Teacher Education, 21, 143-155. http://dx.doi.org/10.1016/j.tate.2004.12.002

Bullough, R. V., \& Draper, R. J. (2004). Making sense of the failed triad: mentors, university supervisors, and positioning theory. Journal of Teacher Education, 55(5), 407-420. http://dx.doi.org/10.1177/0022487104269804

Burns N., \& Grove S.K. (2005). The practice of nursing research: Conduct, critique \& utilization. Elsevier Saunders, St Louis.

Chen, W. -C. (2012). Professional growth during cyber collaboration between pre-service and in-service teachers. Teaching and Teacher Education, 28(2), 218-228. http://dx.doi.org/10.1016/j.tate.2011.09.010

Chinn P.L., \& Kramer M.K. (1999). Theory and nursing a systematic approach. Mosby Year Book, St Louis.

Crasborn, F., \& Hennissen, P. (2010). The skilled mentor: Mentor teachers' use and acquisition of supervisory skills. Eindhoven: Eindhoven School of Education.

Crasborn, F., Hennissen, P., Brouwer, N., Korthagen, F., \& Bergen, T. (2010). Capturing mentor teachers' reflective moments during mentoring dialogues. Teachers and teaching: Theory and practice, 16(1), 7-29. http://dx.doi.org/10.1080/13540600903475462

Elo. S., \& Kynga. S. H. (2008). The qualitative content analysis process. Journal of Advanced Nursing 62(1), 107-115. http://dx.doi.org/10.1111/j.1365-2648.2007.04569.x

Eraut, M. (2007). Learning from other people in the workplace. Oxford Review of Education, 33, 403-422. http://dx.doi.org/10.1080/03054980701425706 
Fairbanks, C. M., Freedman, D., \& Kahn, C. (2000). The role of effective mentors in learning to teach. Journal of Teacher Education, 51(2), 102-112. http://dx.doi.org/10.1177/002248710005100204

Fajet, W., Bello, M., Leftwich, S. A., Mesler, J. L., \& Shaver, A. N. (2005). Pre-service teachers' perceptions in beginning education classes. Teaching and Teacher Education, 21(6), 717-727. http://dx.doi.org/10.1016/j.tate.2005.05.002

Feiman-Nemser, S. (1990). Teacher preparation: Structural and conceptual alternatives. In W. Houston (Ed.), Handbook of research on teacher education (pp. 212-233). New York: Macmillan.

Glickman, C., \& Bey, T. (1990). Supervision. In R. Houston, M. Haberman \& J. Sikula (Eds.), Handbook of research on teacher education: A project of the association of teacher educators (pp. 549-566). New York: Macmillan.

Goodnough, K., Osmond, P., Dibbon, D., Glassman, M., \& Stevens, K. (2009). Exploring a triad model of student teaching: Pre-service teacher and cooperating teacher perceptions. Teaching $\& \quad$ Teacher $\quad$ Education, 25(2), 285-296. http://dx.doi.org/10.1016/j.tate.2008.10.003

Graham, B. (2006). Conditions for successful field experiences: Perceptions of cooperating teachers. Teaching and Teacher Education, 22, 1118-1129. http://dx.doi.org/10.1016/j.tate.2006.07.007

Hall, K. M., R. Draper, R. J., Smith, L. K., \& Bullough Jr, R.V. (2008). More than a place to teach: Exploring the perceptions of the roles and responsibilities of mentor teachers. Mentoring and Tutoring, 16(3), 328-345. http://dx.doi.org/10.1080/13611260802231708

Hawkey, K. (2006). Emotional intelligence and mentoring in pre-service teacher education: A literature review. Mentoring \& Tutoring: Partnership in Learning, 14(2), 137-147. http://dx.doi.org/10.1080/13611260500493485

Hennissen, P., Crasborn, F., Brouwer, N., Korthagen, F., \& Bergen, T. (2011). Clarifying pre-service teacher perceptions of mentor teachers' developing use of mentoring skills. Teaching and Teacher Education, 27, 1049-1058. http://dx.doi.org/10.1016/j.tate.2011.03.009

Hiebert, J., Gallimore, R., \& Stigler, J. (2002). A knowledge base for the teaching profession: What would it look like and how can we get one? Educational Researcher, 31(5), 3-15. http://dx.doi.org/10.3102/0013189X031005003

Le Maistre, C., Boudreau, S., \& Pare, A. (2006). Mentor or evaluator? Assisting and assessing newcomers to the professions. The Journal of Workplace Learning, 18(6), 344-354. http://dx.doi.org/10.1108/13665620610682071

Lederman R.P. (1991) Content analysis of word texts. MCN. The American Journal of Maternal Child Nursing, 16, 169. http://dx.doi.org/10.1097/00005721-199105000-00015 
Lincoln Y. S., \& Guba E. G. (1985). Naturalistic inquiry. Sage, Beverly Hills, CA.

Lindgren, U. (2005). Experiences of beginning teachers in a school-based mentoring program in Sweden. Educational Studies, 21, 251-263. http://dx.doi.org/10.1080/03055690500236290

Katz, L. (2003). The developmental stages of teachers. In L. Katz (Ed.), Talks with teachers of young children: A collection. Norwood, NJ: Ablex.

Kessels, J., \& Korthagen, F. (1996). The relationship between theory and practice: back to the $\begin{array}{llll}\text { classics. } & \text { Educational }\end{array}$ http://dx.doi.org/10.3102/0013189X025003017

Knežić, D., Wubbels, Th., Elbers, E. P. J. M., \& Hajer, M. (2010). The socratic dialogue and teacher education. Teaching and Teacher Education, 26(4), 1104-1111. http://dx.doi.org/10.1016/j.tate.2009.11.006

Marable, M., \& Raimondi, S. (2007). Teachers' perceptions of what was most (and least) supportive during their first year of teaching. Mentoring \& Tutoring: Partnership in Learning, 15, 25-37. http://dx.doi.org/10.1080/13611260601037355

Moir, E. (2003). Launching the next generation of teachers through quality induction. Santa Cruz, CA: New Teacher Centre, University of California.

Nilsson, P., \& van Driel, J. (2010). Teaching together and learning together- Primary science student teachers' and their mentors' joint teaching and learning in the primary classroom. Teaching and Teacher Education, 26(6), 1309-1318. http://dx.doi.org/10.1016/j.tate.2010.03.009

Rajuan, M., Beijaard D., \& Verloop, N. (2007). The role of the cooperating teacher: Bridging the gap between the expectations of cooperating teachers and student teachers. Mentoring \& Tutoring: Partnership in Learning, 15, 223-242. http://dx.doi.org/10.1080/13611260701201703

Rippon, J. H., \& Martin, M. (2006). What makes a good induction supporter? Teaching and Teacher Education, 22, 84-99. http://dx.doi.org/10.1016/j.tate.2005.07.004

Schwille, S.A. (2008). The professional practice of mentoring. American Journal of Education, 115(1), 139-167. http://dx.doi.org/10.1086/590678

Spilková, V. (2001). Professional development of teachers and student teachers through reflection on practice. European Journal of Teacher Education, 24(1), 59-65. http://dx.doi.org/10.1080/02619760120055899

Stanulis, R. N., \& Russell, D. (2000). "Jumping in": trust and communication in mentoring student teachers. Teaching and Teacher Education, 16(1), 65-80. http://dx.doi.org/10.1016/S0742-051X(99)00041-4

Sundli, L. (2007). Mentoring: A new mantra for education? Teaching and Teacher Education, 23, 201-214. http://dx.doi.org/10.1016/j.tate.2006.04.016 


\section{Macrothink}

International Journal of Education

ISSN 1948-5476 2014, Vol. 6, No. 3

Van Ginkel, G., Vermunt, J., Verloop, N., \& Beijaard, D. (2005). Conceptions of mentoring and learning to teach in Dutch secondary student teaching. Paper presented at the European Association for Research in Learning and Instruction. Nicosia, Cyprus

Veenman, S., \& Denessen, E. (2001). The coaching of teachers: Results of five training studies. Educational Research and Evaluation, 7, 385-417. http://dx.doi.org/10.1076/edre.7.4.385.8936

Williams, E. A., Butt, G., Gray, C., Leach, S., Marr, A., \& Soares, A. (1998). Mentors' use of dialogue within a secondary initial teacher education partnership. Educational Review, 3, 225-239. http://dx.doi.org/10.1080/0013191980500302

Zeichner, K. (1996). Designing educative practicum experiences for prospective teachers. In Zeichner, Melnick, \& Gomez (Eds.), Currents of reform in pre-service teacher education. New York: Teachers College Press.

\section{Copyright Disclaimer}

Copyright reserved by the author(s).

This article is an open-access article distributed under the terms and conditions of the Creative Commons Attribution license (http://creativecommons.org/licenses/by/3.0/). 